The Journal of Bone E Joint Surgery
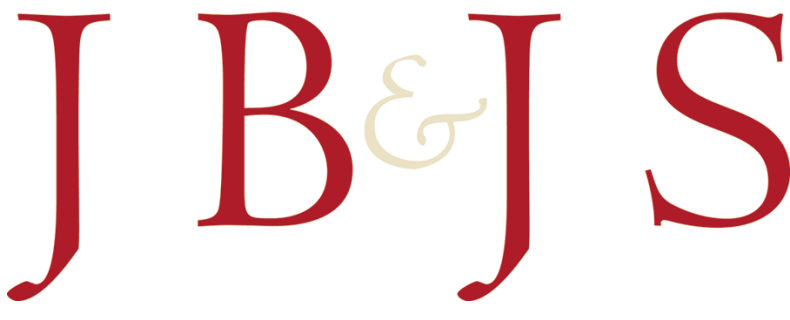

This is an enhanced PDF from The Journal of Bone and Joint Surgery

The PDF of the article you requested follows this cover page.

\title{
Treatment of Congenital Pseudarthrosis of the Tibia with Recombinant Human Bone Morphogenetic Protein-7 (rhBMP-7) A Report of Five
} Cases

Francis Young-In Lee, Stefano M. Sinicropi, Fred Suin Lee, Michael G. Vitale, David P. Roye, Jr. and In Ho Choi J Bone Joint Surg Am. 2006;88:627-633. doi:10.2106/JBJS.D.02201

This information is current as of August 28, 2009

Reprints and Permissions

Publisher Information
Click here to order reprints or request permission to use material from this article, or locate the article citation on jbjs.org and click on the [Reprints and Permissions] link.

The Journal of Bone and Joint Surgery

20 Pickering Street, Needham, MA 02492-3157

www.jbjs.org 


\title{
Treatment of Congenital PSEUdARTHRosis OF THE TIBIA with Recombinant Human Bone Morphogenetic Protein-7 (RHBMP-7)
}

\author{
A Report of Five Cases \\ By Francis Young-In Lee, MD, PhD, Stefano M. Sinicropi, MD, Fred Suin Lee, MD, \\ Michael G. Vitale, MD, David P. Roye JR., MD, AND In Ho Choi, MD, PhD
}

Investigation performed at the Department of Orthopaedic Surgery, Children's Hospital of New York, Columbia University, New York, NY

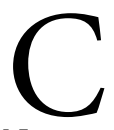

ongenital pseudarthrosis of the tibia is one of the most frustrating conditions encountered in pediatric orthopaedics because of the difficulty in achieving healing. Numerous treatment options have been explored with varying degrees of success ${ }^{1-19}$. Although some reports have demonstrated successful healing ${ }^{7,9,19}$, it is very difficult to restore the normal structural and functional integrity of the bone such as that which occurs after treatment of other types of fractures in children $^{4,10,16}$.

Advances in molecular biology have provided a better understanding of the mechanisms of fracture-healing as well as possible new solutions for the problem, including the use of bone morphogenetic protein (BMP $)^{20-24}$. In a controlled, prospective, randomized study of 124 tibial nonunions (in 122 adult patients) treated with insertion of an intramedullary rod and recombinant human (rh) BMP-7, no significant difference $(\mathrm{p}=0.939)$ was noted between the BMP group and the group that received an intramedullary rod and autogenous iliac crest bone grafts $^{20}$. In a prospective, randomized, controlled, single-blind study of 450 patients with an open tibial fracture, patients who were treated with rhBMP$2(1.50 \mathrm{mg} / \mathrm{mL})$ had significantly $(\mathrm{p}=0.005)$ superior results compared with patients who were treated with intramedullary nail fixation and routine soft-tissue management as dictated by the injury ${ }^{21}$. These two large clinical series suggest that BMPs may be a good alternative to autogenous iliaccrest bone-grafting.

Bone morphogenetic proteins have shown promising results in experimental animal models, and their clinical efficacy has been shown in the treatment of adult tibial nonunions and in spinal fusion ${ }^{20-24}$. They have not been tested in children because of uncertainty as to the effect on adjacent physes and because of concern about unexpected reactions. The use of BMP to treat congenital pseudarthrosis of the tibia is a logical approach because the results from both animal studies and human trials have suggested that BMP is effica- cious in bone-healing. This prospective study was undertaken to determine the clinical efficacy and safety of the use of rhBMP-7 for the treatment of congenital pseudarthrosis of the tibia in skeletally immature patients and to compare the results with those of previously published studies in which autogenous iliac-crest bone grafts have been used in conjunction with various fixation methods.

\section{Materials and Methods}

W e conducted a prospective clinical trial of the use of W BMP in five consecutive patients with congenital pseudarthrosis of the tibia. The use of rhBMP-7 (osteogenic protein1 [OP-1]; Stryker Biotech, Hopkinton, Massachusetts) and a prospective clinical study protocol were approved by the institutional review board of the Children's Hospital of New York and Columbia University. Informed consent for the use of rhBMP-7 was obtained from the parents of the patients. The use of clinical and radiographic materials was approved by the parents in accordance with the Health Insurance Portability and Accountability Act. We chose rhBMP-7 over rhBMP-2 because the former had been approved for use in the treatment of tibial nonunion, whereas rhBMP-2 had received only provisional approval for its use, in conjunction with a cage, during anterior spinal fusion ${ }^{25-27}$. The families of our patients were informed that data concerning the cases would be submitted for publication.

\section{Patients}

Between October 2002 and March 2003, five patients underwent an osteosynthesis procedure with use of rhBMP-7 and intramedullary nail fixation. Four of the five patients also had unilateral external fixation, and one patient (Case 1) had Ilizarov external fixation. The mean age of the patients at the time of surgery was six years (range, seven months to thirteen years). Four patients had undergone a mean of three prior surgical procedures (range, one to four procedures). Table I 
The Journal of Bone \& JOINT SURGERY • JBIS. ORG VOLUME 88-A · Number 3 - MARCH 2006
Treatment of Congenital Pseudarthrosis OF THE TIBIA WITH RHBMP-7

TABLE I Demographic Data on the Patients and the Outcomes Following Treatment with rhBMP-7

\begin{tabular}{|c|c|c|c|c|}
\hline Case & $\begin{array}{l}\text { Sex, } \\
\text { Age }(y r)\end{array}$ & $\begin{array}{c}\text { Type of } \\
\text { Pseudarthrosis* }\end{array}$ & $\begin{array}{l}\text { Limb-Length } \\
\text { Discrepancy }(\mathrm{cm})\end{array}$ & Surgical Procedures \\
\hline 1 & $\mathrm{~F}, 8$ & III & 1 & $\begin{array}{l}\text { rhBMP-7, intramedullary nailing, and long-leg cast for } 4 \text { mo. Revi- } \\
\text { sion surgery at } 7 \text { mo with } 7 \mathrm{mg} \text { of rhBMP-7, } 6 \mathrm{~mL} \text { of bone marrow, } \\
30 \mathrm{~mL} \text { of corticocancellous bone allograft, and llizarov application }\end{array}$ \\
\hline 2 & $F, 12$ & III & 5 & $\begin{array}{l}3.5 \mathrm{mg} \text { of rhBMP-7, corticocancellous allograft bone chips, and in- } \\
\text { tramedullary nailing. External fixation for tibial lengthening }(5 \mathrm{~cm})\end{array}$ \\
\hline 3 & $\mathrm{M}, 1$ & III & 2.5 & $\begin{array}{l}3.5 \mathrm{mg} \text { of rhBMP- } 7 \text {, corticocancellous allograft bone chips, in- } \\
\text { tramedullary nailing, and external fixation for tibial lengthening } \\
(2 \mathrm{~cm})\end{array}$ \\
\hline 4 & $\mathrm{~F}, 5$ & IV & 3 & $\begin{array}{l}7 \mathrm{mg} \text { of rhBMP-7, corticocancellous bone graft, and external } \\
\text { fixation for tibial lengthening }(2.5 \mathrm{~cm})\end{array}$ \\
\hline 5 & M, 4 & IV & 5 & $\begin{array}{l}3.5 \mathrm{mg} \text { of rhBMP-7, corticocancellous allograft bone chips, in- } \\
\text { tramedullary nailing, and primary distraction with external fixator } \\
(2.5 \mathrm{~cm})\end{array}$ \\
\hline
\end{tabular}

summarizes the prior surgical treatment and the type of pseudarthrosis according to the classification system described by Crawford ${ }^{28,29}$, in which type I indicates anterolateral bowing of the tibia; type II, anterolateral bowing with increased cortical thickness, a narrow medullary canal, and a tubular defect; type III, a cystic lesion; and type IV, the presence of a fracture, a cyst, or a frank pseudarthrosis.

Functional outcome was analyzed before and after the procedure according to the criteria developed by Johnston, in which grade 1 indicates unequivocal union; grade 2 , an equivocal union (a residual transverse or longitudinal cortical deficiency) and/or deformity (usually $>15^{\circ}$ of valgus, procurvatum, or recurvatum); and grade 3 , a persistent nonunion or refracture $^{7}$. The five patients had a mean lower-extremity length discrepancy of $3.3 \mathrm{~cm}$ (range, 1 to $5 \mathrm{~cm}$ ). Four patients were able to walk with a knee-ankle-foot total-contact orthosis that had an anterior and posterior shell. One patient was an infant. One patient had pain at the nonunion site preoperatively. Three of the five patients had neurofibromatosis; the other two had no associated disorders.

\section{Surgical Treatment}

An anterior midline skin incision was made over the nonunion site. After the removal of local, dense fibrous tissue, rhBMP-7 (3.5 mg) mixed with a type-I collagen carrier and corticocancellous allograft bone graft was applied around the nonunion site. Scrupulous attention was paid to removing any abnormal tissue posteriorly so that healthy soft tissues would be in contact with the rhBMP-7. The bone ends were resected back to healthy-appearing bone. A tourniquet was used during the procedure so that the integrity of the rhBMP-7 allograft composite would be well maintained until the end of the procedure. Three patients had a second tibial osteotomy after which a concomitant limb-lengthening procedure was performed over an intramedullary nail, away from the nonunion site, to treat a limb-length discrepancy. A unilateral external fixation device was applied in four patients, and an Ilizarov device was used in one.

We applied static compression to achieve apposition of the bone ends at the site of the nonunion. Dynamic compression was not applied. One patient (Case 5) who had overlapping of the bone segments at the nonunion site and a $5-\mathrm{cm}$ lower-extremity length discrepancy had primary tibial distraction at the nonunion site with a unilateral external fixator. One patient (Case 1) was treated with intramedullary nailing and an above-the-knee cast and had placement of rhBMP-7 alone, without supplemental allograft. This patient required an additional procedure because of failure of union at seven months postoperatively and underwent the placement of another $7 \mathrm{mg}$ of rhBMP-7 with $6 \mathrm{~mL}$ of bone marrow along with application of an Ilizarov frame.

\section{Clinical and Radiographic Evaluation}

All patients were evaluated preoperatively and were followed postoperatively at four-week intervals. Non-weight-bearing anteroposterior and lateral radiographs of the involved extremity were made at the preoperative examination, and followup radiographs were made at four-week intervals until one year postoperatively. Four patients underwent a technetium-99m bone scan six months postoperatively.

Healing of the nonunion, incorporation of the rhBMP-7 allograft composite, resorption of the allograft, radiographic changes in the appearance and size of the proximal and distal tibial physes, and the lower-extremity length discrepancy were recorded and analyzed. Lower-extremity lengths were measured radiographically on scanograms. Functional outcome 
The Journal of Bone \& JoInt Surgery - JBJS.Org VOLUME 88-A · Number 3 - MARCH 2006
Treatment of Congenital PSEudarthrosis OF THE TIBIA WITH RHBMP-7

\begin{tabular}{|c|c|c|c|c|}
\hline \multirow{2}{*}{$\begin{array}{l}\text { Radiographic } \\
\text { Evidence of Union }\end{array}$} & \multirow{2}{*}{$\begin{array}{l}\text { Follow-up } \\
\text { (mo) }\end{array}$} & \multicolumn{2}{|c|}{ Outcome (grade) $\dagger$} & \multirow[b]{2}{*}{ Remarks } \\
\hline & & Preop & Postop & \\
\hline Nonunion at $18 \mathrm{mo}$ & 18 & 3 & 3 & $\begin{array}{l}4 \text { prior ops (intramedullary nailing and iliac crest bone-grafting, bone- } \\
\text { grafting } \times 2 \text {, and Ilizarov application); transient sterile drainage }\end{array}$ \\
\hline Union at $6 \mathrm{mo}$ & 15 & 3 & 1 & $\begin{array}{l}4 \text { prior ops (intramedullary nailing and iliac crest bone-grafting, bone- } \\
\text { grafting } \times 2 \text {, and Ilizarov application); neurofibromatosis but no other } \\
\text { complications }\end{array}$ \\
\hline Nonunion at $12 \mathrm{mo}$ & 14 & 3 & 3 & No prior ops; neurofibromatosis but no other complications \\
\hline Nonunion at $12 \mathrm{mo}$ & 12 & 3 & 3 & $\begin{array}{l}1 \text { prior op (intramedullary nailing and iliac crest bone-grafting); failed } \\
\text { prior electromagnetic stimulation. Neurofibromatosis but no other } \\
\text { complications }\end{array}$ \\
\hline Nonunion at $12 \mathrm{mo}$ & 14 & 3 & 3 & $\begin{array}{l}2 \text { prior ops (intramedullary nailing and iliac crest bone-grafting, and } \\
\text { vascularized fibular grafting); no other complications }\end{array}$ \\
\hline
\end{tabular}

was graded before and after the procedure according to the criteria described by Johnston ${ }^{7}$. Complications such as infection, drainage, and wound dehiscence were recorded.

\section{Radiographic and Functional Outcome}

Preoperatively, the lesions were classified as type III (Cases 1, 2 , and 3 ) and type IV (Cases 4 and 5) according to the radiographic classification system of Crawford ${ }^{28,29}$. All five patients had an associated pseudarthrosis of the fibula.

\section{Case Reports}

CASE 1. An eight-year-old girl with a Crawford type-III $\checkmark$ pseudarthrosis and no associated disorders demonstrated no evidence of healing and underwent revision surgery with use of $7 \mathrm{mg}$ of rhBMP-7, corticocancellous bone allograft, and bone-marrow aspirates at seven months following the index procedure. Subsequently, there was a persistent transverse cortical deficiency and most of the allograft was resorbed. The bone scan at six months postoperatively was negative.

CASE 2. A twelve-year-old girl with neurofibromatosis and a Crawford type-III lesion had undergone four prior surgeries and demonstrated complete union at six months (Figs. 1-A, $1-B$, and $1-C)$. This patient gained $5 \mathrm{~cm}$ in limb length as a result of a simultaneous lower-extremity lengthening procedure. Complete cortical restoration and continuity was noted, and alignment was satisfactory. Incorporation of the rhBMP-7 allograft composite was not observed radiographically. The bone scan was negative.

CASE 3. A one-year-old boy with neurofibromatosis and no history of surgery had recurrent anterior angulation and an obvious Crawford type-III pseudarthrosis at the most recent follow-up examination. There was increased bone density and hypertrophy at the pseudarthrosis site. The bone scan was negative.

CASE 4. A five-year-old girl with neurofibromatosis and a Crawford type-IV lesion showed deficient healing on radiographs at the time of the one-year follow-up, although $2.5 \mathrm{~cm}$ of the lengthened segment had consolidated well. The bone scan was negative.

CASE 5. A four-year-old boy with a Crawford type-IV congenital pseudarthrosis of the tibia was treated with intramedullary nailing and external fixation. The patient had gradual tapering of the tibia without angular deformity at the pseudarthrosis site. The rhBMP-7 allograft bone composites were gradually resorbed (Figs. $2-\mathrm{A}$ through $2-\mathrm{D})$. The bone scan was negative.

All five patients met the criteria of a Johnston grade-3 outcome preoperatively. After the rhBMP-7 implantation and other surgical treatment, the outcome score improved to grade 1 in one patient (Case 2) and remained as grade- 3 congenital pseudarthrosis of the tibia in the other four patients (Cases 1, 3, 4, and 5).

Radiographically, the allograft bone and the rhBMP-7 composite appeared to be gradually resorbed without the formation of new bone. Technetium bone scintigraphy did not reveal radioisotope uptake in the regions in which the bone graft and rhBMP-7 bone composite were applied around the nonunion sites.

\section{Complications}

Neither abnormal growth nor angular deformity developed 
The Journal of Bone \& JOINT SURGERY • JBIS. ORG VOLUME 88-A · NUMBER 3 - MARCH 2006
Treatment of Congenital Pseudarthrosis OF THE TIBIA WITH RHBMP-7 in our patients in any areas other than at the pseudarthrosis site following the use of rhBMP-7. The proximal and distal tibial physes remained unchanged in radiographic appearance. Postoperatively, the patients did not experience fever, rash, or any other systemic illness. One patient had sterile serous drainage from the wound. A first-generation cephalosporin antibiotic was administered to the patient for five days. The drainage included fine granules of corticocancellous allograft bone. Early surgical intervention was not undertaken because the cultures were persistently negative, there was a lack of systemic symptoms, the laboratory values were normal, and the wound had a benign appearance. The cause of the drainage, which eventually stopped after eight weeks, was uncertain; however, because there was never any definitive evidence of infection and the bone scan was negative at six months, we believe that the drainage was not a cause of the persistent nonunion.

\section{Discussion}

Congenital pseudarthrosis of the tibia remains one of the $\checkmark$ most difficult pediatric orthopaedic disorders because it is highly resistant to current treatment methods ${ }^{1-18}$. In a multicenter review of 340 patients who underwent 1287 surgical procedures, the European Paediatric Orthopaedic Society reported that the rate of union ranged from $28 \%$ to $75 \%{ }^{6}$. These patients had many different procedures, and few definitive conclusions were drawn. Anderson et al. demonstrated that intramedullary nailing, with use of the technique described by Williams, and autogenous bone-grafting resulted in union of an established pseudarthrosis in nine of ten patients ${ }^{1}$. In a multicenter study of different treatment options, Grill et al. found that treatment of 108 tibiae with the Ilizarov method combined with other techniques resulted in eighty-one unions $(75 \%)$, which was the highest of any procedure analyzed ${ }^{6}$. A recent study by Johnston demonstrated that a grade-1 outcome was obtained in five of

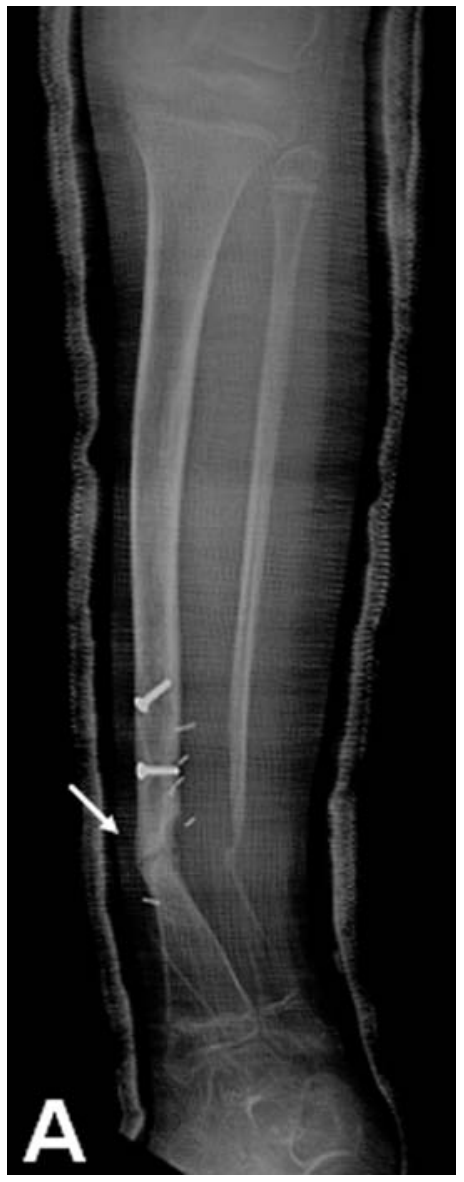

Fig. 1-A

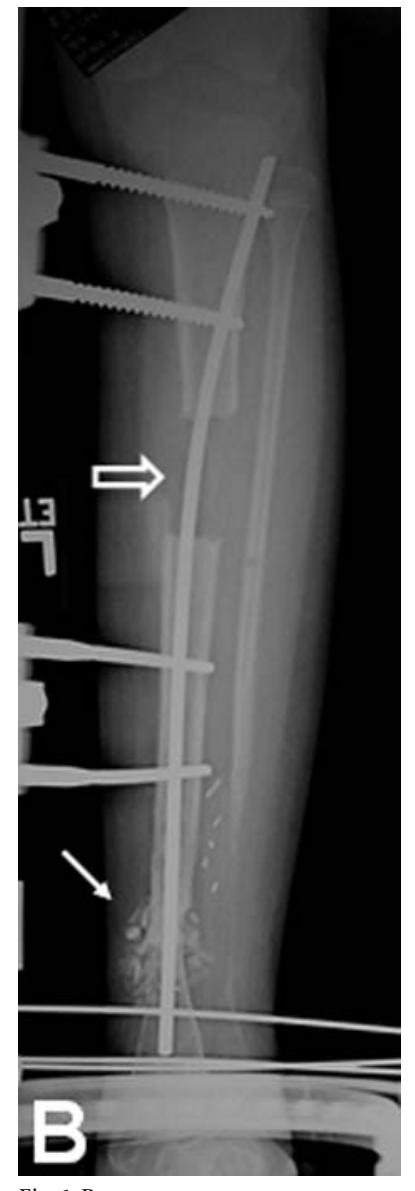

Fig. 1-B

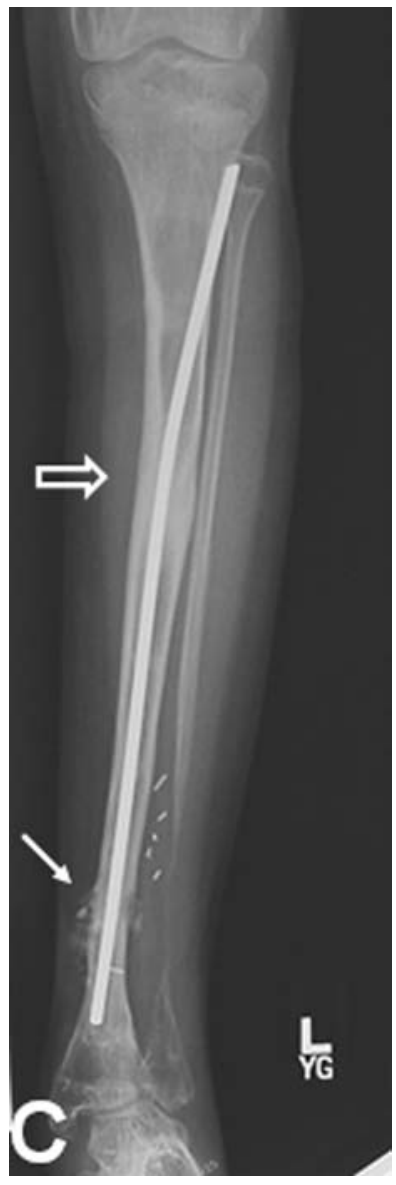

Fig. 1-C

Figs. 1-A, 1-B, and 1-C Case 2. A twelve-year-old girl who had had bone transport with use of an Ilizarov device when she was five years old. A longleg cast was applied after the development of increasing pain and anterior angulation. Fig. 1-A Radiograph made after the patient wore a long-leg cast for four months shows no improvement. The white arrow indicates a persistent fracture line, with recurrent angulation. There is resorption of bone on the concave side. Fig. 1-B Radiograph made three months after treatment with rhBMP-7 demonstrating proximal limb-lengthening of $5 \mathrm{~cm}$ (open arrow) and a nonunion site with circumferentially transplanted corticocancellous bone allografts mixed with 0.5 mg of rhBMP-7 (solid arrow). Fig. 1-C Radiograph made at the time of the one-year follow-up, demonstrating cortical healing but resorption of the transplanted allografts (solid arrow). The lengthened segment consolidated completely (open arrow). The patient had a Johnston grade-1 outcome. 
The JOURnAL of BOnE \& JOINT SURGERY • JBJS.ORG VOLUME 88-A · NUMBER 3 · MARCH 2006
Treatment of Congenital Pseudarthrosis OF THE TIBIA WITH RHBMP-7 twenty-three patients after only one surgical procedure consisting of intramedullary nailing and autogenous iliac-crest bonegrafting 7 . With additional surgery, six more patients achieved a grade-1 outcome, or complete union. One of the critical factors for a favorable outcome was fibular osteotomy. Dormans et al. reported that eleven of twelve patients had union after a free vascularized fibular transfer ${ }^{4}$. At the other extreme, one study showed that fourteen of thirty patients required amputation because the exremities remained dysfunctional after multiple attempts (a mean of 4.7 procedures) ${ }^{16}$. We know of no published reports on the use of BMPs in the treatment of congenital pseudarthrosis of the tibia.

Since the first description of the osteogenic potential of proteins extracted from bone by Urist ${ }^{30}$, numerous studies have provided a scientific rationale for the use of BMPs in human fractures or spinal fusions ${ }^{25,30-34}$. In the two largest reported clinical series, rhBMP- $7^{20}$ and rhBMP- $2^{21}$, which work through nearly identical mechanisms, seemed to be alternative or possibly superior bone-graft substitutes, perhaps with the ability to replace autogenous iliac-crest bone graft. Although these early clinical results demonstrated promise in the treat- ment of fractures in adults, the results of BMP treatment were modest compared with the results from animal studies. Because a single dose of BMP does not govern the entire fracturehealing process, it may not solve the most challenging problems of congenital pseudarthrosis of the tibia. Other critical factors may be the length of time that the BMP remains at the pseudarthrosis site and whether healthy progenitor cells are present. In our patients, new bone formation around the pseudarthrosis site was virtually absent in response to rhBMP-7. Technetium-99m bone-scanning did not reveal any radioisotope uptake in the area of the rhBMP-7 and corticocancellous allografts. When healing occurred in the one patient (Case 2), it was achieved through cortical appositional healing rather than by a bridging callus. One patient (Case 1) underwent a repeat application of BMP-7 mixed with a bone-marrow aspirate and corticocancellous allograft at seven months. At the time of the second surgical procedure, abundant dense fibrous tissue was noted around the pseudarthrosis site. There was no evidence of new bone formation in the areas in which the first dose of rhBMP-7 had been placed.

One of the compounding factors that may have caused



Fig. 2-A

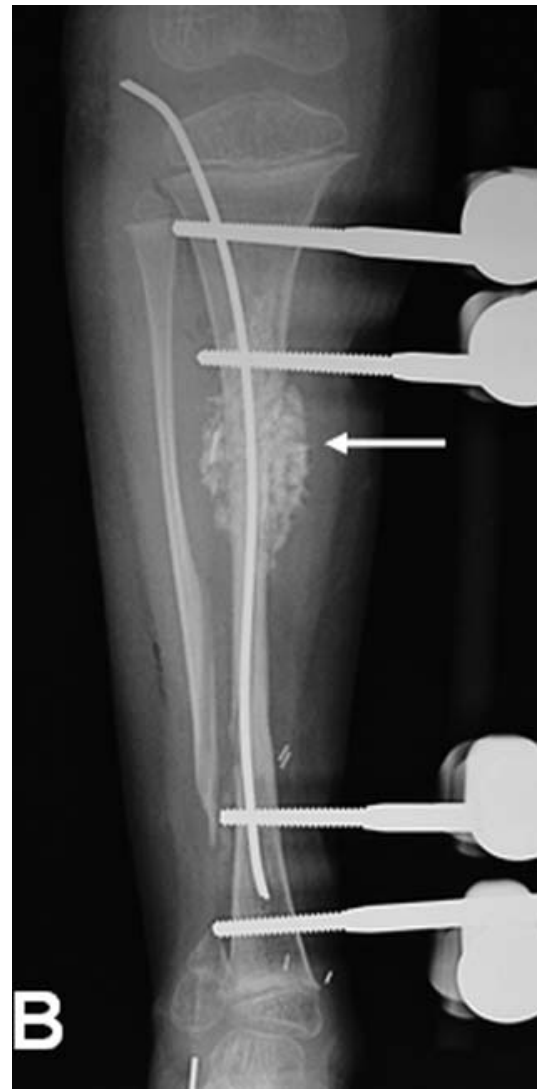

Fig. 2-B

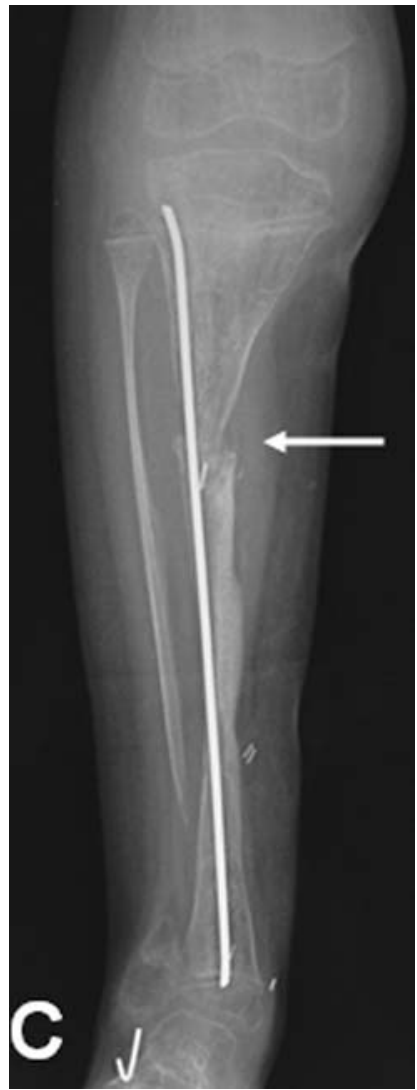

Fig. 2-C

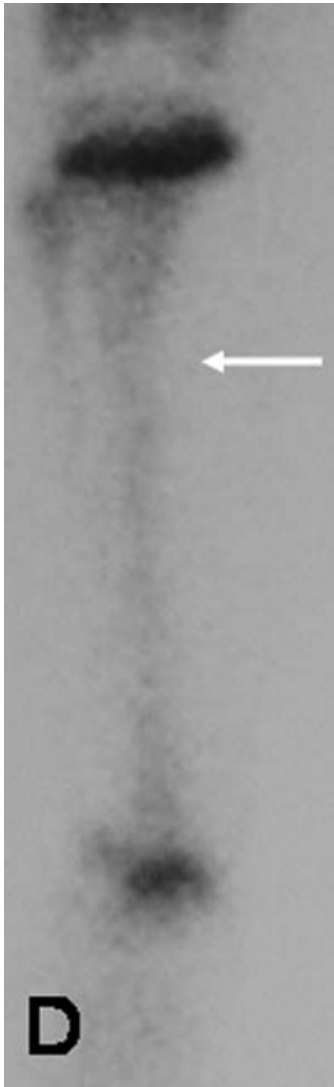

Fig. 2-D

Figs. 2-A through 2-D Case 5. A four-year-old boy. Fig. 2-A Radiograph made following vascularized fibula transfer (arrow), demonstrating nonunion, shortening, and malalignment of the tibia. Fig. 2-B Radiograph made after placement of corticocancellous allograft bone grafts mixed with $3.5 \mathrm{mg}$ of rhBMP-7 (arrow). The patient underwent gradual intraoperative distraction with the aid of external fixation. Fig. 2-C Radiograph made at the time of the one-year follow-up, demonstrating deficient healing and nearly complete resorption of bone grafts (arrow). Fig. 2-D Technetium-99m bone scintigram made at six months, demonstrating lack of radioisotope uptake in the region in which the rhBMP-7 and bone grafts were applied (arrow). 
The Journal of Bone \& JoINT SURGERY · JBJS.ORG Volume 88-A · Number $3 \cdot$ March 2006
Treatment of Congenital Pseudarthrosis OF THE TIBIA WITH RHBMP-7 poor healing in our series is the high degree of stiffness of the unilateral external fixators. Four patients had such frames applied. Although we were able to restore the mechanical axis and maintain alignment with the unilateral external fixators, we did not create the mechanical compression that is unique to the Ilizarov device ${ }^{5,6}$. Successful clinical results have been reported following the use of the Ilizarov device, perhaps reflecting the importance of mechanical compression, which can promote a better biologic stimulus for healing.

With regard to safety, no side effects associated with the use of either rhBMP-7 or the type-I collagen carrier were noted and there were no radiographic changes in the proximal or distal tibial physes or abnormal bone growth related to the use of rhBMPs. One patient had persistent sterile drainage of fine granules of corticocancellous bone grafts through an incompletely healed wound; the drainage stopped spontaneously after two months.

In conclusion, we believe that the use of BMPs alone may not be enough to overcome the poor healing environment that is associated with congenital pseudarthrosis of the tibia. A single application of $3.5 \mathrm{mg}$ of rhBMP-7 combined with a type-I collagen and corticocancellous allograft bone graft did not result in enhanced bone healing in our patients.
Francis Young-In Lee, MD, $\mathrm{PhD}$

Stefano M. Sinicropi, MD

Michael G. Vitale, MD

David P. Roye Jr., MD

Department of Orthopaedic Surgery, Center for Orthopaedic Research, Columbia University, 622 West 168th Street, BHN 816, New York, NY 10032. E-mail address for F.Y.-I. Lee: fl127@columbia.edu

In Ho Choi, MD, $\mathrm{PhD}$

Department of Orthopaedic Surgery, Seoul National University Hospital, 28 Yongon-dong Chongno-gu, Seoul, Korea 110-744

Fred Suin Lee, MD

1608 Lemoine Avenue, Fort Lee, NJ 07024

The authors did not receive grants or outside funding in support of their research for or preparation of this manuscript. They did not receive payments or other benefits or a commitment or agreement to provide such benefits from a commercial entity. No commercial entity paid or directed, or agreed to pay or direct, any benefits to any research fund, foundation, educational institution, or other charitable or nonprofit organization with which the authors are affiliated or associated.

doi:10.2106/JBJS.D.02201

\section{References}

1. Anderson DJ, Schoenecker PL, Sheridan JJ, Rich MM. Use of an intramedullary rod for the treatment of congenital pseudarthrosis of the tibia. J Bone Joint Surg Am. 1992;74:161-8.

2. Baker JK, Cain TE, Tullos HS. Intramedullary fixation for congenital pseudarthrosis of the tibia. J Bone Joint Surg Am. 1992;74:169-78.

3. Charnley J. Congenital pseudarthrosis of the tibia treated by the intramedullary nail. J Bone Joint Surg Am. 1956;38:283-90.

4. Dormans JP, Krajbich JI, Zuker R, Demuynk M. Congenital pseudarthrosis of the tibia: treatment with free vascularized fibular grafts. J Pediatr Orthop. 1990;10:623-8.

5. Ghanem I, Damsin JP, Carlioz H. Ilizarov technique in the treatment of congenital pseudarthrosis of the tibia. J Pediatr Orthop. 1997;17:685-90.

6. Grill F, Bollini G, DungI P, Fixsen J, Hefti F, Ippolito E, Romanus B, Tudisco C, Wientroub S. Treatment approaches for congenital pseudarthrosis of tibia: results of the EPOS multicenter study. European Paediatric Orthopaedic Society (EPOS). J Pediatr Orthop B. 2000;9:75-89.

7. Johnston CE 2 nd. Congenital pseudarthrosis of the tibia: results of technical variations in the Charnley-Williams procedure. J Bone Joint Surg Am. 2002;84:1799-810.

8. Joseph B, Somaraju VV, Shetty SK. Management of congenital pseudarthrosis of the tibia in children under 3 years of age: effect of early surgery on union of the pseudarthrosis and growth of the limb. J Pediatr Orthop. 2003;23:740-6.

9. Kim HW, Weinstein SL. Intramedullary fixation and bone grafting for congenital pseudarthrosis of the tibia. Clin Orthop Relat Res. 2002;405:250-7.

10. Lehman WB, Atar D, Feldman DS, Gordon JC, Grant AD. Congenital pseudoarthrosis of the tibia. J Pediatr Orthop B. 2000;9:103-7.

11. Morrissy RT, Riseborough EJ, Hall JE. Congenital pseudarthrosis of the tibia. J Bone Joint Surg Br. 1981;63:367-75.

12. Paterson DC, Simonis RB. Electrical stimulation in the treatment of congenital pseudarthrosis of the tibia. J Bone Joint Surg Br. 1985;67:454-62.

13. Plawecki S, Carpentier E, Lascombes P, Prevot J, Robb JE. Treatment of congenital pseudarthrosis of the tibia by the llizarov method. J Pediatr Orthop. 1990;10:786-90.

14. Romanus B, Bollini G, Dungl P, Fixsen J, Grill F, Hefti F, Ippolito E, Tudisco C, Wientroub S. Free vascular fibular transfer in congenital pseudoarthrosis of the tibia: results of the EPOS multicenter study. European Paediatric Orthopaedic Society (EPOS). J Pediatr Orthop B. 2000;9:90-3.
15. Toh S, Harata S, Tsubo K, Inoue S, Narita S. Combining free vascularized fibula graft and the llizarov external fixator: recent approaches to congenital pseudarthrosis of the tibia. J Reconstr Microsurg. 2001;17:497-509.

16. Traub JA, O'Connor W, Masso PD. Congenital pseudarthrosis of the tibia: a retrospective review. J Pediatr Orthop. 1999;19:735-8.

17. Tudisco C, Bollini G, Dungl P, Fixen J, Grill F, Hefti F, Romanus B, Wientroub S. Functional results at the end of skeletal growth in 30 patients affected by congenital pseudoarthrosis of the tibia. J Pediatr Orthop B. 2000;9:94-102.

18. Umber JS, Moss SW, Coleman SS. Surgical treatment of congenital pseudarthrosis of the tibia. Clin Orthop Relat Res. 1982;166:28-33.

19. Dobbs MB, Rich MM, Gordon JE, Szymanski DA, Schoenecker PL. Use of an intramedullary rod for the treatment of congenital pseudarthrosis of the tibia. A long-term follow-up study. J Bone Joint Surg Am. 2004;86:1186-97.

20. Friedlaender GE, Perry CR, Cole JD, Cook SD, Cierny G, Muschler GF, Zych GA, Calhoun JH, LaForte AJ, Yin S. Osteogenic protein-1 (bone morphogenetic protein7 ) in the treatment of tibial nonunions. J Bone Joint Surg Am. 2001;83 Suppl 1(Pt 2):S151-8

21. Govender S, Csimma C, Genant HK, Valentin-Opran A, Amit $Y$, Arbel R, Aro $H$, Atar D, Bishay M, Borner MG, Chiron P, Choong P, Cinats J, Courtenay B, Feibel R, Geulette B, Gravel C, Haas N, Raschke M, Hammacher E, van der Velde D, Hardy P, Holt M, Josten C, Ketterl RL, Lindeque B, Lob G, Mathevon H, McCoy G, Marsh D, Miller R, Munting E, Oevre S, Nordsletten L, Patel A, Pohl A, Rennie W, Reynders P, Rommens PM, Rondia J, Rossouw WC, Daneel PJ, Ruff S, Ruter A, Santavirta S, Schildhauer TA, Gekle C, Schnettler R, Segal D, Seiler H, Snowdowne RB, Stapert J, Taglang G, Verdonk R, Vogels L, Weckbach A, Wentzensen A, Wis niewski T; BMP-2 Evaluation in Surgery for Tibial Trauma (BESTT) Study Group. Recombinant human bone morphogenetic protein-2 for treatment of open tibial fractures: a prospective, controlled, randomized study of four hundred and fifty patients. J Bone Joint Surg Am. 2002;84:2123-34.

22. Baskin DS, Ryan P, Sonntag V, Westmark R, Widmayer MA. A prospective, randomized, controlled cervical fusion study using recombinant human bone morphogenetic protein-2 with the CORNERSTONE-SR allograft ring and the ATLANTIS anterior cervical plate. Spine. 2003;28:1219-25.

23. Boden SD, Kang J, Sandhu H, Heller JG. Use of recombinant human bone morphogenetic protein-2 to achieve posterolateral lumbar spine fusion in humans: a prospective, randomized clinical pilot trial. Spine. 2002;27:2662-73.

24. Johnsson $R$, Stromqvist $B$, Aspenberg $P$. Randomized radiostereometric study comparing osteogenic protein-1 (BMP-7) and autograft bone in human noninstru- 
The Journal of Bone \& JOINT SURGERY $\cdot$ JBJS.ORG VOLUME 88-A · NUMBER 3 - MARCH 2006
Treatment of Congenital Pseudarthrosis

OF THE TIBIA WITH RHBMP-7 mented posterolateral lumbar fusion. Spine. 2002;27:2654-61.

25. Boden SD, Zdeblick TA, Sandhu HS, Heim SE. The use of rhBMP-2 in interbody fusion cages. Definitive evidence of osteoinduction in humans: a preliminary report. Spine. 2000;25:376-81.

26. Haid RW Jr, Branch CL Jr, Alexander JT, Burkus JK. Posterior lumbar interbody fusion using recombinant human bone morphogenetic protein type 2 with cylindrical interbody cages. Spine J. 2004;4:527-39.

27. Mummaneni PV, Pan J, Haid RW, Rodts GE. Contribution of recombinant human bone morphogenetic protein-2 to the rapid creation of interbody fusion when used in transforaminal lumbar interbody fusion: a preliminary report. Invited submission from the Joint Section Meeting on Disorders of the Spine and Peripheral Nerves, March 2004. J Neurosurg Spine. 2004;1:19-23.

28. Crawford AH. Neurofibromatosis in childhood. Instr Course Lect. 1981;30:56-74.

29. Crawford AH. Neurofibromatosis in the pediatric patient. Orthop Clin North Am. 1978;9:11-23.
30. Urist MR. Bone: formation by autoinduction. Science. 1965;150:893-9.

31. Cook SD, Baffes GC, Wolfe MW, Sampath TK, Rueger DC. Recombinant human bone morphogenetic protein-7 induces healing in a canine long-bone segmental defect model. Clin Orthop Relat Res. 1994;301:302-12.

32. Lee FY, Storer S, Hazan EJ, Gebhardt MC, Mankin HJ. Repair of bone allograft fracture using bone morphogenetic protein-2. Clin Orthop Relat Res. 2002;397:119-26.

33. Suh DY, Boden SD, Louis-Ugbo J, Mayr M, Murakami H, Kim HS, Minamide A, Hutton WC. Delivery of recombinant human bone morphogenetic protein-2 using a compression-resistant matrix in posterolateral spine fusion in the rabbit and in the non-human primate. Spine. 2002;27:353-60.

34. Martin GJ Jr, Boden SD, Marone MA, Marone MA, Moskovitz PA. Posterolateral intertransverse process spinal arthrodesis with rhBMP-2 in a nonhuman primate: important lessons learned regarding dose, carrier, and safety. J Spinal Disord. 1999;12:179-86. 